\title{
TÜRK HUKUKUNDA TOPLU SÖZLEŞME ERKI VE SINIRLARI
}

Dr. Fażl SAGLAM

Anayasa'mizin 47. maddesi sosyal devlet ilkesinin somut kurallamndan biri olarak aşağıdaki hükmü getirmiştir :

MADDE 4\% : İşciler, işverenleriyle olan münasebetlerinde, iktisadî ve sosyal durumlarını korumak ve düzeltmek amacıyla toplu sözleşme ve grev hakkına sahiptirler.

Grev hakkının kullanılması ve istisnaları ve işverenlerin hakları kanunla düzenlenir.

Bu kural iki açıdan önemlidir :

1) Sosyal devlet kavramının özünü teşkil eden işçiyi koruma ilkesi, bu madde içinde açık bir biçimde dile gelmektedir.

2) Modern anlamda kollektif is hukukunun temel kurumlarinı oluşturan toplu sözleşme erki ve grev hakkı bu ilkeye bağlı olarak anayasal güvence altına alınmıştır.

Biz bu yazıda toplu sözleşme erki üzerinde duracağız. Ancak daha önce koruma ilkesinin 47. madde içindeki önemini vurgulamak, toplu sözleşme erkinin anlaşılması için zorunludur. Bu yapıldıktan sonra toplu sözleşme erkinin özü, hukukî kaynağı ve sınırları ele alınacaktır.

\section{Koruma ilkesinin 4\%. madde içindeki anlam ve önemi :}

Anayasa'nın 47. maddesi bir yandan çalışrna koşullarının oluşumunda serbest pazarlık ilkesini saklı tutarken, öte yandan bu ilkeye sosyal bir sinir çizmektedir.

Yani Anayasa, işçilere, iktisadî ve sosyal durumlarını işverenlerle birlikte düzenlemeleri için özerk bir alan tanımıs ve böylece iktisadî yaşamın özgürlüğü esasını korumuştur. Yasama ve yürütmenın bu alana müdahalesi, ancak koruma amacinın gerektirdiği ölçüde olmalıdır. (')

(1) Kars. NIPPERDEY, Lehrbuch des Arbeitsrechts, II. Bd., 7. Aufl., Berlin 1967, S. 44; BIEDENKOPF, Grenzen der Tarifautonomie, Karlsiuhe 1964, S. 
Ancak, bu alanda anlamlı ve sosyal bir sözleşme özgürlüğünden söz edebilmek için $\left(^{2}\right)$ çalışma koșullarının eşit güicteki taraflar arasinda pazarlık konusu yapılması gerekir. İşi ve işveren arasında ise böyle bir eşitliğin bulunmadığı açıtır. İşte Anayasa'mız bu eşitliği hukukî yoldan sağlamak için toplu sözleşme erkini belli bir amaca bağlamıştır : Toplu iş sözleşmesi «işçlerin iktisadî ve sosyal durumlarını korumak ve düzeltmek amacina» hizmet etmelidir.

Bunun tașıdiğı anlam şudur :

a. Toplu iş sözleşmesi, işçilerin şimdiye kadar ulaştıkları iktisadî ve sosyal durumu geriye götürücü bir araç olarak düzenlenemez. $\left({ }^{3}\right)$

b. Toplu iş sözleşmesi, işçilerin iktisadî ve sosyal durumlarını düzeltmek amacına yönelmelidir.

Koruma amacinın bir anayasal ilke olarak tanınmış olması 47. maddenin sözünden açıkca anlaşılmaktadır. Bu konuda Anayasa tek yanlı davranmıştır. Madde yalnızca iş@ilerin toplu sözleşme ve grev haklarından söz etmektedir. İşveren toplu is sözleşmesinin doğal tarafı olduğu halde, 47. maddede toplu sözleşme hakkının sahibi olarak gösterilmemiştir. Bu bir raslantı değildir. Bunun nedeni Anayasa koyucunun koruma amacını yalnız işçiler için gerekli görmüş olmasıdır. Yine aynı nedenle 47. maddede lokavta anayasal bir güvence tanınmamıs, yasa koyucunun düzenlemesine bırakılmıştır.

Öte yandan koruma amacı zaten sosyal devlet ilkesinin özünü tesskil eder. 47. madde ise toplu sözleșme ve grev alanında bu amacın somut bir ifadesidir. Denilebilir ki Yüksek mahkemelerimiz de 47. maddenin bu yönünü kavramıs durumdadır.

Yargitay 9. Hukuk Dairesi'nin 9.4.1968 tarih ve E. 157, K. 4628 sayılı bir kararında şöyle deniliyor :

«... tereddüt hâlinde iş̧inin lehine olan hal şeklinin kabul edilmesi, İs Hukuku'nun ana kaidelerindendir.. Toplu iş sözleşmelerinin T. C. Anayasası'nda düzenleme biçimleri de hukukumuz açısından bu yoldaki bir yorum gereğini yeterince açılar..»

Anayasa Mahkemesi'nin 20.10.1967 tarih ve E. 1963/337, K. 178 vd; RAMM, Der Arbeitskampf und die Gesellschaftsordnung des Grundges-
etzes, Stuttgart 1965, s. 158 .

(2) NIPPERDEY, age, s. 43.

(3) RAMM, age, s. 158. 
1967/31 sayılı kararında da bir çok açılardan bu ilkeye dayanılmıştir. Bir iki cümle ile yetiniyoruz : $\left({ }^{4}\right)$

«.. 5 - 10 işçiye .. toplu iş sözleşmesi yapma yetkisinin tanınması, Anayasa'nın toplu sözleşme ve grev yapma yetkilerini tanıması ile güttüğü ereğe .. karşıt bulunmaktadır. Gerçekten toplu sözleşme yapma yetkisi, işçilerin sosyal ve iktisadî durumlarını düzeltmek için onlara tanınmiștır.

Anayasa'nın 47. maddesindeki «işçiler sözünden, güçlü işçi kuruluşlarında, .. birleşmiş işçileri anlatmak istediği, Anayasa'nın herkesten önce işçileri korumak ereği ile bu hükmü koymuş bulunduğu göz önünde tutularak kabul olunmalıdır.»

\section{Toplu sözleşme erkinin özü}

Toplu sözleşme erkinin özü, kaynağını teşkil eden Anayasa'dan çıarılmalıdır. Anayasa'nın 47. maddesinde güvence altına alınan «toplu sözleşme hakkı» genel sözleşme özgürlüğünün bir tekrarı değildir. Eğer anayasa koyucu bununla toplu iş sözleşmesi taraflar için kendine özgü bir yetki tesis etmek istemeseydi, 40. madde ile tanıdığı sözleşme özgürlüğü yanında toplu sözleşmeden ayrica söz etmek gereğini duymazdı. Toplu sözleşmeye Anayasa'da ayrıca yer verilmiş olması, doğrudan doğruya ve tek yanlı zorlayı etkisiyle birlikte modern bir toplu sözleşme sistemini güvence altına almak içindir. Bu etkiyi irade özerkliğinden, akit serbestisinden çlkarmak mümkün değildir. Çünkü irade özerkliği «işlevsel bir bağı bulunmamak, meşruluğunu kendi içinde taşımak» anlamına gelir. ( ${ }^{5}$ ) İade özerkliğinden oluşan kurallar, insan haysiyeti ile meşruluk kazanır, herhangi bir diş amaca bağlı değildir. $\left({ }^{6}\right)$ Buna karşılık toplu is sözleşmesi ile yapılan düzenleme, üçüncü kişilerin sorumluluğunu üzerinde tașır. Başka bir deyişle toplu is sözleșmesinde sözleşmeye katılmamış olan üçüncü kişilerin hukukî ilişkileri düzenlenir. $\left.{ }^{7}\right)$ Bura-

(4) Metinler için bkz. AMKD, Sayı 6, s. 57 - 58.

(5) BIEDENKOPF, age, s. 29.

(6) BIEDENKOPF, age, s. 30.

(7) Kars. GALPERIN, Die autonome Rechtsetzung im Arbeitsrecht, Molitor Festschrift 1962 , s. 143 ; BIEDENKOPF, age, s. 31 . ZOLLNER, Die Rechtsnatur der Tarifnormen, Wien, 1966, bunu bir ayırıcı kistas olarak görmüyor. Ona göre yabancı iradenin bağlanması irade özerkliği alanında da söz konusudur; "Temsil" veya "yenilik doğuran haklar» bunun örnekleridir. Gerçi bu örneklerde düzenlemeye tâbi olan kimse, hukukî işleme doğrudan doğruya katılmamıştır. Ancak burada kurala bağlılık kendi iradesine dayanır. Yani düzenlemeye tâbi olanın iradesi ile kurala bağlılık arasında sıkı bir bağ mevcuttur. Toplu iş sözleşmesi ile yapllan düzenlemede ise bu bağ çok gevşektir. Sendi- 
da söz konusu olan şey, toplu iş sözleşmesi taraflarının hukuk düzenince tanınmıs, beli bir amaca bağll, özgün bir yetkiye sahip olmalaridir. $\left({ }^{3}\right)$

$\mathrm{Bu}$ nedenle toplu iş sözleşmesi taraflamnın, maddi anlamda hukuk kuralları koymak, ya da dolaylı etkiye sahip hükümler getirmek suretiyle üçüncü kişilerin hukukî ilişkilerini düzenleyecekleri özerk bir alana sahip kılınmalar gerekir. Isste toplu sözleşme erki derken kastettiğimiz budur. Anayasa'nın 47. maddesinde güvence altına alınan «toplu sözleşme hakkı» da böyle bir anlam taşır.

Anayasa'nın 47. maddesinin tahlili, toplu sözleşme erkinin unsurlarını yeterince ortaya koymaktadır.

a. Toplu sözleşme erki ile ișci ve işveren arasındaki ilişkiler düzenlenir.

b. Toplu sözleşme erki, iktisadî ve sosyal alanda söz konusudur. Çalışma koşulları bu alanın merkezini olușturur.

c. Toplu sözlesme erki belli bir amaca bağlıdır : «İsçilerin iktisadî ve sosyal durumlarını korumak ve düzeltmek». Amaca bağlılığın nedeni, işverenlerin fiilî üstünlügüünü dengeleme zorunluğudur. Buna göre toplu sözleşme erki, işçiler açısından güçlï sendikalarca kullanılmalıdır. Toplu iş sözleşmesi normlarının doğrudan doğruya ve tek yanlı zorlayıcı etkisi de böyle bir amaca bağlılığın sonucudur. Kısacası toplu sözlesme erki meşruluk kaynağını, koruma düşüncesinden alır.

d. Toplu sözleşme erkine sahip olanlarca yapılacak düzenlemelerin biçimi «toplu sözleşmedir». Yani kurallar bir sözleşme içinde koyulur.

e. Toplu sözleşme ile yapılan düzenlemeler, işçi tarafı açısından daima, sözleșmenin yapılışına katılmamış bulunan üçüncü kişilere yöneliktir. Yani bu düzenleme en azından işçi tarafı için üçüncü kişilerin sorumluluğunu taşır.

Bu durum, bir hukuk devletinde her hukuk kuralı için zorunlu sayılan bir koşulu da birlikte getirir. Toplu sözleşme erkini kullananlar, düzenlemeye muhatap olanlarca meşru kılınmalidir. ( ${ }^{9}$ ) 275 sayıl Yasa'ya göre bu meşruiyet, yasaya eş etkideki kurallar açı-

ka üyeliği, düzenlemenin geçerlilik nedeni değil bir koşuludur. Karş. NIPPERDEY age, s. 350 , dip not 23; BIEDENKOPF, age, s. 52.

(8) BIEDENKOPF, age, s. 31.

(9) Kars, BIEDENKOPF- age, s. 47 vd. 
sindan, ilke olarak toplu sözleşmeye ehil sendikaya girmekle sağlanmış olur. Ancak toplu sözleşme erkinin zaten çoğunluk sendikalarınca kullanılabilmesi (TSGLK m. 7), böyle bir meşruiyet için genel olarak yeterlidir. Bu nokta, dolayl etkiye sahip kurallar (yani toplu sözleşmenin borçlar hukukuna ilişkin hükümleri) açısından önemlidir.

Bu kısa analize göre toplu sözleşme erki, toplu iş sözleşmesi taraflamın özerk alanları içindeki iş̧̧i ve işverenlerin iktisadî ve sosyal ilişkileri üzerinde sahip olduklam kural koyma erki olarak tanımlanabilir.

Toplu sözleșme erkinin daha yakın düzenlemesi, 275 sayılı Toplu İs Sözleșmesi, Grev ve Lokavt Kanunu (TSGLK) ile yapılmıştir.

\section{Toplu sözleşme erkinin hukukî kaynağ}

Türk Anayasası, 47. maddesiyle toplu sözleşme hakkını tanımak suretiyle, toplu iş sözleşmesi taraflar için özerk bir düzenleme alanı yaratmıştır. Bu alan en azından özü bakımından devletin yasama (ve düzenleme) erki dişındadır. Böylece Alman Hukukunda çok savunulan «delegasyon teorisi»nin $\left({ }^{10}\right)$ hukukumuzda geçerli olamıyacağı ortaya çıkar. Çünkü yasa koyucunun delegasyonuna dayanan bir kural koyma yetkisi, onun tarafindan her zaman geri alınabilir. Oysa Anayasa'nın 47. maddesi, yasamadan bağımsız özerk bir alanı garanti etmektedir. Şu halde toplu sözleşme erkinin yasa koyucu tarafindan delege edilmesine gerek yoktur, çünkü bu erk kaynağını doğrudan doğruya Anayasa'dan alır.

Uygulamada da toplu iş sözleşmesi taraflarmın bu özgün düzenleme yetkisinin bilincinde olduklarını söyleyebiliriz. Taraflar toplu sözleşme düzenini kendi meseleleri olarak kabul etmekte, kendilerini devletin bir görevlisi olarak görmemektedirler ").

Böylece devletin yasama gücü ile toplu sözleşme erkinin aynı

(10) Buna göre toplu sözleşme erki yasa koyucunun delegasyonuna dayanir. Bkz. BAG AP Nr. 4 zu Art. 3 GG; HUECK-NIPPERDAY-STAHLHACKE, Tarifvertragsgesetz (Kommentar), 4. Aufl. Berlin, 1964, s. 1, Anm. 181; NIKISCH, Arbeitsrecht Bd. II. 2. Aufl.. Tübingen 1959, s. 45 Buna karşlık "Entegrasyon teorisi", toplu sözleşme erkini Alman Anayasasının 9. maddesinin III. fikrasına dayandırmaktadır. Bkz. GALPERIN, age, s. 153 vd., BIEDENKOPF, age, s. 102. vd. SCHNORR, Inhalt und Grenzen der Tarifautonomie, JR 1966, s. 329 vd.

(11) GALPERIN, age, s. 154.

(12) GALPERIN, age, s. 157; BIEDENKOPF, age, s. 104. 
hukuk kaynağına, yani Anayasa'ya dayandıklamnı söylemek ( $\left.{ }^{12}\right)$ Türk Hukuku için doğru bir yargı olur.

Toplu iş sözleşmesi ile ilgili yasa hükümleri yalnızca somutlaştırncı bir dïzenlemedir.

\section{Toplu sözleșme erkinin sınurları}

Toplu sözleşme erkinin sınırları özellikle hukukumuz açısından çözümü güç bir sorundur. Toplu sözleşme düzeni hukukumuzda oldukça yenidir. Toplu iş sözleşmesi diğer Avrupa ülkelerinde uzunca bir uygulama sürecinin kendiliğinden ortaya çıkardığı bir kurumdur. Sonradan bu konuda çkarilan yasalar, böyle bir gelişimin deneylerinden yararlanmıs, toplu iş sözleşmesinin kavram ve sorunları, bu gelişimle olan bağlantısı içinde açıklığa kavuşturulabilmiştir. Oysa bizde toplu sözleşme kurumu uygulamadan çıkmamış, tersine Anayasa ve hukuk düzenimizce oluşturulmaya çalışılmıştır. Bu amaçla yabancı hukuk düzenlerinden aktarmalar yapılmıștır. İşte uygulamadaki deney eksikliği, toplu sözleşme erkinin sınırları konusunda yaplacak bir çalışmayı teorik bir deneme düzeyinde bırakacaktır. Bu çalışmaya da aynı gözle bakılmalıdır.

\section{Genel olarak}

a. Toplu sözleşme erkinin sınırları ilke olarak hukukî kaynağı ile belirlenir. Anayasamız bu açıdan bazı pozitif dayanaklara sahiptir. Bunun yanında Anayasa ile bağdaştığı ölçüde 275 sayılı Yasa'nın getirdiği sınırlamalar da dikkate alınmalıdır.

b. Toplu sözleşme erkinin amacı, sınırlarının tespitinde de belirleyici bir rol oynar, Amaç «işçilerin iktisadî ve sosyal durumlarinı korumak ve düzeltmektir.»

Koruma amacının çıkıs noktası işverenin fiilî gücüdür. $\mathrm{Bu} d u-$ rum kendisini yalnızca bireysel hizmet ilişkilerinde göstermez; işçi ve işveren arasındaki bütün iktisadî ve sosyal ilişkiler bu damgayı taşır. Bu nedenle koruma ilkesi, yalnız hizmet ilişkisine inhisar etmez, bütün iktisadî ve sosyal alana yaygındır. Burada bir nokta önemlidir. Koruma ilkesi, işçilerle birey olarak değil, bir sosyal grubun mensupları olarak ilgilenir. Burada söz konusu olan, birbirinden izole durumda münferit işçilerin korunması değildir. İş̧ilerin iktisadî ve sosyal durumları bir sosyal bütün olarak korunmalı ve düzeltilmelidir. Demek ki koruma amacını gerçekleștirmek üzere işverenin fiilî gücünü dengelemek, yalnız bireysel alanda değil, kollektif alanda da gereklidir. 


\section{Toplu sözleşme erkinin konu bakımundan sınurları}

a. Anayasa'nın 47. maddesinden anlaşıldığına göre, işçi ve işveren arasında, işçinin iktisadî ve sosyal durumunu ilgilendiren tüm ilişkiler, toplu sözleşme erkinin konusuna girer. Başka bir deyişle işçilerin işverenleriyle olan ilişkilerinde iktisadî ve sosyal durumlar-1 nı korumaya ya da düzeltmeye elverişli her konu, toplu sözleşme erkinin de konusudur.

$\mathrm{Bu}$ geniş düzenleme alanı 275 sayılı Yasa ile daraltılmış değildir. $\mathrm{Bu}$ yasanın 1. maddesinin ilk fıkrası toplu is sözleşmesinin özü diyebileceğimiz konuları düzenler. Bunlar «hizmet aktinin yapılmas1, muhtevası, ve sona ermesiyle ilgili hususlardir $\left({ }^{13}\right)$. Aynı yasanın 3. maddesi, doğrudan doğruya ve zorlayıcı etkiyi bu hükümlere inhisar ettirmiştir. 1. maddenin 2. fıkrası ise genel bir hüküm niteliğindedir. Buna göre «işçi ve işveren münasebetlerini ilgilendiren diğer hususlar» da toplu sözleşme konusu yapılabilir $\left({ }^{14}\right)$. Demek ki hizmet aktinin yapılması, muhtevası, ve sona ermesi ile ilgisi olmayan başka hususlar da toplu sözleşme erkinin kapsamı içindedir. Denebilir ki toplu sözleşme erkinin konusu bakımından Anayasa'nın 47. maddesi ile 275 sayılı Yasa arasında bir sınır farkı yoktur.

Toplu iş sözleşmesi ile gttirilen «başka hükümlerin» 275 sayllı Yasa'nın 1. maddesinin ilk fıkrasındaki normlardan farkı, aynı Yasa'nın bu hükümlere doğrudan doğruya ve zorlayıcı etkiyi bağlamamıs olmasıdır. Ancak bunlar, toplu sözleşme erkinin konusu olmakta devam eder ve taraflar arasinda doğuracağı borç sayesinde dolaylı bir etki sağlar.

b. Anayasa'nın 47. maddesinin gerekçesinden de anlaşıldığı gibi, anayasa koyucu «iktisadî ve sosyal durum» formülü ile katı bir sınir çizmek istememiștir. Gerekcede yalnızca grev hakkı ile ilgili olarak, neyin iktisadî ve sosyal alan dışında kaldığı belirtilmiştir :

(13) Bunları toplu iş sözleşmesinin borç doğuran hükümlerinden ayırmak ve yasaya benzer niteliğini vurgulamak için "toplu sözleşme normları» ya da «normatif hükümler» deyimleri kullanılmaktadır. Metinde zaman zaman kullandığımız «norm» terimi de bu anlamdadır.

(14) Isviçre B. K.'nun 322. maddesi bu konuda daraltıcı gibi gözüken bir ifade kullanıyor : «.. iş̧̧i ve işveren ilişkilerini ilgilendirdiği ölçüde..» Buna rağmen SCHWEINGRUBER - Kommentar zum Gesamtarbeitsvertrag, Bern. 1963 , s. 41 , mehaz metnin bu ifadesini geniş bir düzenleme yetkisi olarak niteliyor. Ona göre, yasa koyucu burada sınırın nerde bittiğini saptamak istememiştir. İ̧çi ve işveren ilişkilerinin kapsamı zaman içinde değişebilir. Kanun bu açıdan bir yasak getirmemiģtir. 
"Bu hakkın siyasî maksatlarla kullanılabilme ihtimalinin yarattığı endişeleri mübalağa etmemek gerekir. Esasen tasarıda yer alan «işverenlerle olan münasebetlerinde iktisadî ve sosyal durumlarını korumak veya düzeltmek maksadıyla kaydı, siyasî grevlerin caiz olmadığını göstermektedir.»

aa. Buna göre siyasal amaçların toplu sözleşme erki dışında kaldığını söyleyebiliriz. $\left(^{15}\right)$ Toplu is sözleşmesi taraflarının bir devlet gücüne yönelen ve gerçekleşmesi belli bir devlet organının karamna bağlı olan talepleri, kuşkusuz «iktisadî ve sosyal alanın» dışında kalır. Bunlamn toplu iş sözleşmesinin konusu yapılamaması, zaten işci ve işveren ilişkilerini ilgilendirmemesinin bir sonucudur.

Buna karşıllk doğrudan doğruya işverene yönelen ve onun tarafından kabule elverişli olduğu halde, gerçekleşmesi devletin belli bir işlemini gerektiren taleplerin toplu iş sözleşmesinin meşru konusu olup olamıyacağını tespit oldukça güçtür. Özellikle devletin işveren olduğu durumlarda bu sorun önem kazanır. Bir işçi sendikasi, herhangi bir iktisadî devlet teşebbüsünde çalışan iş̧ilerin ücretlerine zam isteyebilir. Böyle bir talebin gerçekleşmesi, devlet bütçesinde yaplacak bir değisiikliğe bağlı olsa bile, zam talebi politik saylamaz. ${ }^{(16)}$ Yani bir işveren olarak devlete yöneltilen bir talebin ancak bir devlet tasarrufu ile gerçekleșebilmesi, bu talebin siyasal nitelikte olmasını gerektirmez. OĞUZMAN'a göre burada genel bir ölçüt koymaya imkân yoktur. Yargị bu konuda önüne gelen her özel durumda kendi takdirine göre bir karara varacaktır. ( $\left.{ }^{17}\right)$

bb) Siyasal konuların yanında dinî konuların da toplu sözleşme erkinin dışında kaldığını söyleyebiliriz. Böyle bir sınırlama anayasal düzenimizin layik niteliğine de uygun düserer. Örneğin namaz odalamnın tahsisi, ya da namaz vakitleri ıçin özel izin gibi talepler toplu iş sözleşmesinin konusu yapılamaz.

c. Bunun ötesinde iktisadî ve sosyal alana kesin sınırlar çizmek olanağı yoktur. Burada «sınırların elastikiyeti» nden $\left(^{18}\right)$ söz açmak daha yerinde olur. Böyle bir anlayıs, iktisadî ve sosyal gelişmenin yenilediği ihtiyaçlara cevap vermeye daha elverişlidir.

İşcilerin, personel sorunları ya da sosyal ve iktisadî sorunlar-

(15) SAYMEN, Toplu Sözleşme Bilgileri, Ankara 1964, s. 30 vd. OĞUZMAN, Hukukí Yönden Grev ve Lokavt, 2. b., İstanbul, 1967, s. 43 vd.

(16) Aynı görüş için bkz. OĞUZMAN, age, s. 45.

(17) OGUZMMAN, age, s. 44.

(18) SCHNORR, age, s, 331. 
da yönetime katılması $\left({ }^{19}\right)$, servet oluşumu ile ilgili ortak edimler, veya meslekî eğitim gibi konular da çalışma koşullar yanında toplu is sözleşmesinin düzenleme alanina girer.

\section{Toplu sözleşme erkinin kiși bakımundan sınırları}

Anayasa'nın 47. maddesi, toplu sözleşme erkinin kişi bakımından ulaşabileceği sinırlar konusunda açık bir fikir vermiyor. $\mathrm{Bu}$ sınırları bir yandan meşruluk ilkesinden ve özerklik kavramının özünden, öte yandan yasal düzenlemeden çıkartabiliriz.

a. Bir hukuk devletinde maddî anlamda objektif hukuk sayılabilecek her düzenleme, kurala muhatap olanlarca meşru kılınmalıdır. $\mathrm{Bu}$ ilke toplu is sözleşmesiyle yapılan düzenlemelerde de geçerlidir. Bu meşruiyet, toplu iş sözleşmesini yapacak olan kuruluşa üye olmakla kuşkusuz sağlanmış olur. Ancak meşruiyeti yalnızca üyelikte görmek $\left({ }^{20}\right)$ hukukumuz açısından anlamsız bir daraltma olur. Toplu sözleşme erki, çoğunluğa dayalı bir kuruluşun temsilî karakteriyle de meşru kılınmış sayılmalıdır. Çünkü çoğunluk, demokratik meşruiyetin temel unsurudur.

Öte yandan üyeliği meşruiyetin tek koşulu saymak, olsa olsa yasa etkisine sahip toplu iş sözleşmesi hükümleri için gereklidir. Aynı gereği borç doğuran hükümler için de şart koşmak bu ilkenin amacını aşar. Çünkü düzenlemeye muhatap olanın üyelik yoluyla düzenlemeyi meşru kılması zorunlu sayılıyorsa, bunun nedeni, yapılan düzenlemenin bir hukuk normu niteliğinde olmasidır. $\left({ }^{21}\right)$ Oysa borç doğrudan hükümlerin böyle bir niteliği yoktur.

b. Özerklik kavramı da toplu sözleşme erkinin kişi bakımından ulaşabileceği sınırlar konusunda bir fikir verebilir. $\left({ }^{12}\right)$ Burada özerklikten anladığımız, devlet dışındaki bir insan grubunun kendi işlerini kendi isteklerince düzenlemeleridir. $\left({ }^{23}\right)$

(19) Karģ. ÇELIK, Türkiye'de toplu iş sözleşmesi ve iģverenin sevk ve idare hakkı, Toplu iş sözleşmesi seminerleri, 1965, s. 109 vd., AKBIYIK, aynı eser, s. 84 vd.

(20) Bu yönde bkz. MAYER-MALY, Leistugsdifferenzierung und Tarif machtbegrenzung, BB 1966, s. 1067 vd.; karşı görüß̧ için bkz. GAMILLSCHEG, Die Differenzierung nach der Gewerkschaftszugehörigkeit, Berlin 1966, s. 94 vd.

(21) Kars. BIEDENKOPE, age, s. 47, s. 53.

(22) Özerklik kavramının doktrinde kullanılan çeşitli anlamları için bkz, ZÖLLNER, age s. 13 vd; ADOMEIT, Rechtsquellefragen im Arbeitsrecht München 1969 , s. 128 vd.

(23) Kars. SCHNORR, age, s. 328; ADOMEIT, Zur Theorie des Tarifvertrages, RdA 1967, s. 304; GALPERIN, age, s. 143. 
Kural koyanlarla kurala tâbi olanlar arasında demokratik bir ilişkinin bulunması, özerk düzenlemenin asgarî koşulunu oluşturur. $\left({ }^{24}\right)$

Bu demektir ki özerk düzenleme ancak, kural koyan organı demokratik ilkelere göre kendi temsilcileri olarak meşru kılmıs olan kimseler üzerinde yapılabilir. Ancak burada belli bir kuruluștan hareket etmek zorunlu değildir. Önemli olan kendileri için özerkliğin söz konusu olduğu insan topluluğunun bütünüdür. Örneğin, belli bir iş kolunda işçilerin çoğunluğu serbest iradeleriyle belli bir sendika çevresinde birleşmişse, bu sendika, sahip olduğu çoğunluk nedeniyle, yalnız kendi üyelerinin değil, bu iş kolunda çalışan tüm işçilerin meşru temsilcisi olarak görülmelidir.

Yasa koyucunun toplu is sözleșmesi ile yapılan düzenlemenin etki derecesine göre özel bir koşul öngörmesi bașka bir sorundur. Örneğin yasa etkisindeki kuralların geçerliliği üyelikle sinırlanabilir ya da aynı kurallar Amerikan Hukuku'nda olduğu gibi toplu is sözleşmesi ile bağlı işverenin bütün işçileri üzerinde etkisini gösterebilir. $\left(^{25}\right)$

Bu nedenle toplu sözleşme özerkliğini yalnızca meslekî kuruluşlamn bir «ko-otonomisi» $\left({ }^{26}\right)$ olarak anlamak en azından yeterli değildir. Burada sözkonusu olan, sendikalamn üyeleri üzerinde sahip olduklar düzenleme yetkisi değil, işçilerin işverenleriyle olan ilişkilerinde kendi sorunlarını kendi isteklerince ortaklaşa düzenleyebilmeleridir. Toplu sözleşme erkinin bu özerklik çerçevesinde kullanılması, koruma amacının gereklerine göre yasa koyucu tarafindan değișik bir düzenlemeye tâbi tutulabilir.

Eğer yasa koyucu toplu iş sözleşmesi normlarının etkisini üyelikle sınırlamıssa, bu durum, çoğunluğa dayalı bir sendikanın işveren tarafiyla, üye olmayanlarla ilgili borç doğuran hükümler getirmesini engellemez. Böylece temsil alanı içindeki üye olmayan işçiler üzerinde de dolaylı bir etkinin sağlanması mümkündür.

c. 275 sayilı Yasa, toplu is sözleşmesi ile bağlllkk konusunda açılk bir hüküm getirmemiștir. Bu yasanın 3. maddesine göre toplu is sözleşmesi normları, hizmet akitleri üzerinde doğrudan doğruya ve zorlayıcı bir etki doğurur. Ancak hangi hizmet akitleri üzerinde

(24) Karş. ZÖLLNER, age, s. 19; ADOMEIT, RdA 67, s. 304.

(25) NIKISCH, age, s. 489 vd, böyle bir yasal düzenlemeyi mümkün görmekte, ancak, bu halde belki de özerklikten söz edilemiyeceğini belirtmektedir.

(26) Bkz. SCHNORR, age, s. 332. 
bu etkinin doğacağı maddede belirtilmemiştir. Bu konuda yasanın 7. maddesinin 3 . bendi ile 6 . maddesi bir sonuç çkarmaya elverişlidir. 7/3. maddeye göre bir toplu iş sözleşmesinin uygulandığı işyerinde çalışan ve üye olmayan işçilerin sözleşmeden yararlanabilmesi, taraf işçi teşekkülüne dayanısma aidatı ödenmesine bağlıdır. $\mathrm{Bu}$ hükmün mevhumu muhalifinden toplu is sözleşmesi normlarının ilke olarak taraf kuruluş üyeleri üzerinde doğrudan doğruya ve zorlayıc1 bir etki doğurduğu anlaşılmaktadır. 6. madde ise taraf işçi sendikası üyeliğinden ayrılanların toplu iş sözleșesi normları ile bağli kalmakta devam edeceğini belirtmektedir. Demek ki buradaki bağlılık daha önceki üyeliğe dayandırılmaktadır. Böylece toplu iş sözleşmesi taraflarının yasa etkisinde kural koyma yetkileri, üyeler ya da dayanışma aidatı ödemek suretiyle kendilerini gönüllü olarak bu yetkiye tâbi kılan diğer işçiler üzerinde söz konusu olabilecektir.

d. Bunun ötesinde, üye olmayanların taraflar arasında borç doğuran hükümler yoluyla dolaylı bir dëzenlemeye tâbi kılınmaları, toplu sözleşme erkinin sinırlarını aşmaz. Borç doğuran hükümler açısından toplu sözleşme erkinin kişi bakımından hangi sınırlara ulaşacağı, toplu is sözleşmesine ehil sendikanın temsil niteliği ile belirlenir. Bunlar, belli bir işyerincle ya da işkolunda çalışan işçilerin çoğunluğunu temsil ettikleri için 275 sayılı Yasa'nın 7. maddesinin 1. bendine göre $o$ iş yeri ya da işkolunu kapsayan toplu iş sözleşmesi yapmaya yetkilidir. İște bu genel yetki, toplu sözleşme erkinin kişi bakımından ulaşacağı sınırı da belirler; Toplu iş sözleşmesine ehil işçi kuruluşu hangi birim üzerinde (işyeri, işyerleri, işkolu) çoğunluğu temsil ediyorsa, o birimin kapsamı içnideki işyerlerinde çalışan işçilerin tümü, $\left({ }^{27}\right)$ toplu sözleşme erkinin kişi bakımından sınırı$\mathrm{nl}$ meydana getirir. $\left({ }^{28}\right)$

(27) Işveren tarafı açısından toplu sözleşme erkinin kişi bakımından s1nırları sorunu önemsizdir. Çünkü işveren sendikalı olsa da olmasa da durum değişmez. Sendikalı ise, üye olarak toplu sözleşme erkine tâbi olur. Ưye değilse, işveren sufatı ile toplu iş sözleşmesine ehil olduğundan, her zaman toplu iş sözleşmesine zorlanabilir.

(28) Toplu iş sözleşmelerinde sık sık raslanan *Taraf işçi kuruluşunun üyesi olmayan işçlerin toplu iş sözleşmesinin getirdiği haklardan yararlanamıyacağı» şeklindeki hüküm, - ki biz buna "tefrik şartı diyoruz- toplu sözleşme erkinin kişi bakımından sınırları sorununu yakından ilgilendirdiği halde, bu yazı çerçevesi içinde genel bir yaklaşımı tercih ettiğimiz için, uygulamada önemli gelişmeler gösteren bu somut sorunu başka bir yazıda ayrıntılı olarak ele almayı düşünüyoruz. Şimdilik böyle bir hükmün yukandaki açılalamalar çerçevesinde toplu sözleşme erkinin sınırları içinde kaldığını belirtmekle yetinelim. Daha geniş bilgi için bkz. SAĞLAM, Der normative Teil des Ta- 


\section{Toplu sözleşme erki ve yasama}

a. Tamamlayıcı hukuk kurallam ile toplu sözleşme erki sınırlanmış olmaz, çünkü toplu is sözleşmesi tarafları her zaman değişik bir düzenlemeye gidebilirler. $\left({ }^{29}\right)$

b. Yasa koyucu Anayasa'nın 11. maddesindeki ilkelere uygun düşmek şartı ile zorlayıcı hükümler getirerek toplu sözleşme erkini sinırlayabilir. Yani, bu sinırlama Anayasa'nın sözüne ve ruhuna uygun olmalıdır. Burada Anayasa'nin temel ilkeleri yaninda koruma amacı özel bir önem kazanır. Çünkü toplu sözleşme erki bu amaçla tanınmıştır. Bu nitelik, amaç dışı yaplacak bir sınırlamanın hakkın özüne dokunması sonucunu doğurur. Şurasını hemen belirtmek gerekir ki yasal sınırlama bakımından toplu sözleşme hakkı ile grev hakkının sinırları farklıdır. Anayasa'nın 47. maddesinin 2. fıkrası "Grev hakkının kullanılması.. kanunla düzenlenir.» hükmünü getirmiştir. Oysa toplu sözleşme hakkı için böyle bir hüküm yoktur. Bu bakımdan grev hakkı için söz konusu olabilecek sınırlamalar, toplu sözleşme açısından ancak koruma amacına uygun düştüğü oranda mümkündür. $\left({ }^{30}\right)$

Örneğin asgarî çalışma koşullam bir yasa ile zorlayıcı olarak düzenlenebilir. Böyle bir düzenleme, işçileri asgarî bir koruma sağladığı ve iktisadî ve sosyal durumlarının düzeltilmesine de engel teşkil etmediği için, koruma amacına uygun bir sınırlamadır. Buna karşlık çalışma koşullarının üst sınırını zorlayıcı olarak düzenlemek, yani işillere daha elverişli koşullarla toplu iş sözleşmesi yapma olanağını kapamak, yalnız amaç dışı bir sınırlama olmaz, aynı zamanda toplu sözleşme erkinin özüne de dokunmuş olur.

\section{Kazanılmış haklar ve geçmişe etkili düzenleme sorunu}

Toplu sözleşme erkinin kazanılmış haklar karşısındaki durumu ve toplu sözleşme normlarının geçmişe etkili olarak düzenlenmesi, toplu sözleşme erkinin sinırları konusuna giren önemli sorunlardır. Alman hukuk öğretisinde geniş tartışmalara yol açmış olan bu sorunların ay. rıntılarına bu yazı çerçevesinde girmeyeceğiz. Bazı temel sorunlara işaret etmekle yetineceğiz.

rifvertrages im türkischen Arbeitsrecht, Kölner Dissertation 1971, s. 75 vd.

(29) NIPPERDEY age, s. 371.

(30) Nitekim Anayasa Mahkemesi de 20.10.1967 tarih ve E. $1963 / 337$, K. 1967/31 sayılı kararında grev hakkının AY m. 47'deki amaç dışında da sınırlandırılabileceğini belirtirken maddenin 2. fıkrasindaki hükme dayanmaktadır. Karar metni için bkz. AYMKD, Sayı 6, s. 74-75. 
Önemli ölçüde taraftar bulan bir görüşe göre, yasalar ve yürütmenin düzenleyici işlemleri için geçerli olan hukuk devleti ilkeleri bu sorunların çözümünde de kullanılmalıdır ${ }^{31}$ ). Hukukumuzda REISOĞLU'nun aynı yaklaşım içinde olduğu söylenebilir ${ }^{32}$ ).

Hukuk deyleti ilkeleri toplu sözleșme normları için uygulanırsa, kazanılmıs hak ve taleplerin toplu sözleşme erkinin sınırları dışında kaldiğı sonucuna varılır.

Geçmișe etkili olarak yapılacak bir düzenleme de yine aynı ilkelere göre, kurahn yürürlük başlangıcı olarak düşünülen tarihte ilgilinin önceden düșünemiyeceği, hesaba katamıyacağı haklara ve hukukî durumlara müdahale sonucunu doğurmamalıdır. ${ }^{33}$

$\mathrm{Bu}$ ilkeler devlet organlarının koyduğu kurallar açısından doğrudur. Ancak bu kuralların bağlı olduğu hukuk devleti ilkelerinin toplu sözleşme erki açısından da kütünüyle uygulanabileceği şüphelidir. Gerçi toplu sözleşme normları, özellikle hukukî etkileri bakımından yasama ve yürütme organının koyduğu kurallara benzerler. Ancak bu normların yasa hükümlerinden ya da yürütmenin düzenleyici işlemlerinden farkı, devletin dışında, özerk bir alan içinde oluşmaları ve bu alan içinde etki doğurmalarıdır. Bu nitelik, toplu sözleşme normlarını bir yönü ile özel hukuk işlemlerine yaklaştırmaktadır. Başka bir deyişle toplu sözleșme normlarında kamu hukuku ve özel hukuk niteliği bir arada görülmektedir..$^{34}$

Burada önemli olan, toplu sözleşme normlarının kamu hukuku karakterini belirleyen olgunun saptanmasıdır. Bizce bu olgu, toplu sözleşme erkinin bağlı olduğu koruma amacıdır. Zaten Anayasa güvencesi de bu amaca bağlı olarak getirilmiștir. Toplu sözleșme normlarının kamu hukuku karakteri koruma amacının gerektirdiği ölçüde ortaya çıkmakta, bu amacın isterleri dışında özel hukuk niteliği ağırlık kazanmaktadir. Bunun en belirgin görünüşü toplu sözleşme normlarının zorlayıcı etkisinin tek yanlı işleyişidir.

Şu halde bu ikili karakter göz önüne alınırsa, yasama ya da yürütmeyi bağlayan hukuk devleti ilkelerinin toplu iş sözleşmesine aynen

31) SCYNORR, age, S. 333; SOLLNER, Zu Sinn und Grenzen der Vereinbarungs befugnis der Tarifvertragsparteien, Au. R. 1966, S. 262

32) REISOGLU, age, S. 249, 253 vd.

33) NIKISCH, age, S. 379

34 Daha geniş olarak bkz. SAGLAM, Der normative Teil des Tarifvertrages im türkischen Arbeitsrecht, Kölner Dissertation, 1971, S. 52-58. 
uygulanabileceğini savunmak güçleşir..s Toplu sözleşme normlarının hukukî niteliği koruma amacıyla belirlendiğine göre, toplu sözleşme erkinin hukuk devleti ilkeleriyle sinırlanması, ancak koruma amacıyla birleştiği yerde mümkün olur. Koruma gereğinin bulunmadığı yerde irade özerkliğine yaklaşıldığından, hukuk devleti ilkelerinin uygulanmasina da gerek kalmaz.

Bu tür bir yaklaşımın daha basit ve daha adil çözümler getireceği inancındayız. Örneğin geçmişe etkili bir ücret indirim, bu yaklaşıma göre gerek koruma amacı ve gerekse hukuk devleti ilkelerine göre geçersizdir. Buna karşılık ücretlerin geçmişe etkili olarak yükseltilmesi koruma amacına uygundur. Bunu hukuk devleti ilkelerine dayanarak sınırlamanın anlamı yoktur. Hele uygulamada, iş kolu düzeyinde yapılan toplu iş sözleşmelerinde bile taraf işveren teşekkülü üyelerinin sözleşmeyi ayrıca tek tek imzaladıkları göz önünde tutulursa, ișverenin serbest iradesini hukuk devleti ilkeleriyle sinırlamanın gereksizliği daha da belirginleşir.

Ayrıca doktrinde, eski sözleşmenin yürürlük süresi ile sözleşmesiz dönem arasında genellikle yapılan (bizce ) suni ayrımlara $\mathrm{da}^{36}$ gerek kalmaz.

35) Bu nokta, bir önceki dip notunda adı geçen doktora tezimizde (bkz. S. 82-84) ihmal edilmiştir.

36) Bu konuda bkz. NIKISCH, age, s. 379; HUECK-NIPPERDEY STAHLHACKE (age, s. 1, Anm, REISOGLU, s. 225 vd. 